\title{
Preliminary study into the landing behaviour on the human body of morning-biting mosquitoes in Atlantic forest in the State of Santa Catarina (Diptera: Culicidae)
}

\author{
Estudo preliminar sobre o comportamento de pouso no corpo humano \\ de mosquitos de atividade matutina em Mata Atlântica \\ no Estado de Santa Catarina
}

\author{
Carlos Brisola Marcondes ${ }^{1}$ and Ueslei Paterno ${ }^{1}$
}

\begin{abstract}
Mosquitoes (22 species) (0.5\%) and Runchomyia reversa (5\%) biting humans in the morning in Florianópolis, State of Santa Catarina, were significantly more common below than above waist and all Wyeomyia incaudata were collected below the waist. Short trousers are not recommended, unless using repellents.
\end{abstract}

Key-words: Culicidae. Runchomyia reversa. Ochlerotatus scapularis. Protection. Landing Behaviour.

\begin{abstract}
RESUMO
Mosquitos ( 22 espécies) (0,5\%) e Runchomyia reversa (5\%), pousando em humanos pela manhã em Florianópolis, Santa Catarina, foram significativamente mais numerosos abaixo da cintura, e todos os Wyeomyia incaudata foram coletados abaixo da cintura. Estes dados reforçam não ser recomendável utilizar calças curtas na floresta, a menos que se usem repelentes.
\end{abstract}

Palavras-chaves: Culicidae. Runchomyia reversa. Ochlerotatus scapularis. Proteção. Comportamento de pouso.

Mosquitoes can transmit several pathogenic agents by the bite to human and to several animals, including Plasmodium spp, helminths and arboviruses. Several methods have been proposed for the personal protection of humans, including repellents and special clothes ${ }^{16}$. Since mosquitoes prefer to land and to bite one or another part of the body, a comprehension of this distribution can be useful for protection.

Studies have indicated different behaviors for the various mosquito species (e.g. ${ }^{37}$ ); Service ${ }^{17}$ revised thoroughly the studies on bait catches of mosquitoes, including the distribution of bites on the body and factors influencing this, such as the elimination of $\mathrm{CO}_{2}$, height of flight and smell.

The growing number of people walking in Atlantic forest, for tourism, research and other activities indicates a need for more knowledge on the biting habits of mosquitoes and on means of protection. Despite the continental dimensions and regional differences of Brazil, the distribution of landing on the human body has only been studied in the Amazon forest ${ }^{3}$.
The landing behaviour of mosquitoes on the human body was studied in the morning in a secondary Attantic forest on the Island of Santa Catarina, State of Santa Catarina, in southern Brazil.

Mosquitoes were collected along a trail in a conservation unit in the North of the Santa Catarina Island ("Unidade de Conservação Ambiental Desterro", henceforward abbreviated UCAD; 27031'50.8" S, 48030'44.3" W), Municipality of Florianópolis, State of Santa Catarina. The unithas been described elsewhere $e^{15}$. Briefly, it has $491.5 \mathrm{ha}$ and is covered by dense Atlantic rain forest, partly damaged many years ago, and now in recuperation; the trail is $971 \mathrm{~m}$ long, with altitudes varying from 25 to $150 \mathrm{~m}$ a.s.l. The collectors, one of them (CBM) wearing short trousers (mid thigh), regatta shirt and boots with short socks, and the other full clothing, collected mosquitoes landing on each of their bodies using suction and plastic tubes. They walked rapidly along the trail, stopping at ten points, and collecting for seven minutes at each one; the points have been

1. Laboratório de Entomologia Médica do Departamento de Microbiologia e Parasitologia do Centro de Ciências Biológicas da Universidade Federal de Santa Catarina, Florianópolis, SC, Brasil.

Partially financed by CNPq (Proc.-690143/01-0).

Address to: Prof. Carlos Brisola Marcondes. Laboratório de Entomologia Médica/DMP/CCB/UFSC. Caixa Postal 476, 88040-900 Florianópolis, SC.

Tel: 5548 331-5208, Fax: 5548 331-9258.

e-mail: cbrisola@mbox1.ufsc.br

Recebido em: 17/08/04

Aceito para publicação em 3/5/2005 
described previously ${ }^{15}$. Collections were started 1-1.5 hours after sunrise, and developed weekly from September to December 2001 (spring). Two collections were done at a point (10) from 7 to 11 a.m., 15 minutes per hour; both were interrupted by strong winds at this hour.

Mosquitoes collected above and below waist were preserved in separate killing bottles, containing ethyl acetate, transferred on the same day to dry boxes, and afterwards fixed, if necessary, to triangles on pins, ready to be identified by the use of keys ${ }^{4} 810$, besides comparison with original descriptions and insects in the collection of Faculdade de Saúde Pública of Universidade de São Paulo, São Paulo. Data were analyzed by ANOVA with one variable.

A total of 353 female mosquitoes were collected (Table 1). They belonged to 22 species, 17 were classified in Sabethini. The statistical analysis was only performed for the mostcommon species (Runchomyia reversa and Ochlerotatus scapularis) . An additional analysis was performed taking the mosquitoes as a whole.

Ru. reversa was significantlymore common below than above the waist (mean: 3 vs. 0.43 mosquitoes/sample; $F=6.56$ vs. $\mathrm{F}_{\text {crit. } 5 \%}=4.0$ ). The difference for Oc. scapularis ( mean: 1.09 vs. $0.77 \mathrm{~m} / \mathrm{sample} ; \mathrm{F}=2.31$ vs. $\mathrm{F}_{\text {crit } 10 \%}=2.78$ ), similar to that of $\mathrm{Ru}$. reversa, was not significant even at $10 \%$. The sum of

Table 1 - Distribution of mosquitoes landing on the human body in Atlantic forest during the morning at Florianópolis, State of Santa Catarina, Brazil

\begin{tabular}{|c|c|c|c|}
\hline Species/ body regions & Above waist & Below waist & Total \\
\hline Aedes albopictus & 1 & - & 1 \\
\hline Anopheles cruzii & 4 & 15 & 19 \\
\hline Culex (Melanoconium) sp & - & 2 & 2 \\
\hline Culex (Mcroculex) sp & - & 1 & 1 \\
\hline Limatus durhami & 5 & - & 5 \\
\hline Ochlerotatus scapularis & 32 & 33 & 65 \\
\hline Ochlerotatus serratus & 4 & 2 & 6 \\
\hline Psorophora ferox & 3 & - & 3 \\
\hline Runchomyia reversa & 10 & 94 & 104 \\
\hline Sabethes (Sabethinus) sp & 1 & - & 1 \\
\hline Sabethes albiprivus & 1 & - & 1 \\
\hline Sabethes aurescens & 1 & - & 1 \\
\hline Shannoniana fluviatilis & 3 & 8 & 11 \\
\hline Trichoprosopon digitatum & 6 & 6 & 12 \\
\hline Wyeomyia bourrouli & 1 & - & 1 \\
\hline Wyeomyia (Pho) davisi & 1 & 3 & 4 \\
\hline Wyeomyia (Den) sp & 1 & - & 1 \\
\hline Wyeomyia (Pho) fuscipes & - & 1 & 1 \\
\hline Wyeomyia (Pho) galvaoi & - & 12 & 12 \\
\hline Wyeomyia (Pho) incaudata & - & 37 & 37 \\
\hline Wyeomyia (Wye) sp & 1 & - & 1 \\
\hline Wyeomyia bourrouli & 2 & - & 2 \\
\hline Wyeomyia (Pho) pallidoventer & - & 4 & 4 \\
\hline Wyeomyia (Pho) palmata & - & 2 & 2 \\
\hline Wyeomyia (Pho) pilicauda & - & 1 & 1 \\
\hline Wyeomyia (Pho) splendida & - & 1 & 1 \\
\hline Wyeomyia (Pho) theobaldi & 3 & 11 & 14 \\
\hline Wyeomyia (Pho) damaged & 5 & 16 & 21 \\
\hline Wyeomyia damaged & 6 & 4 & 10 \\
\hline Culicidae damaged & 1 & 8 & 9 \\
\hline Total & 92 & 261 & 353 \\
\hline
\end{tabular}

mosquitoes below the waist was significantly higher than above ( mean: 3.33 vs. $1.25 \mathrm{~m} / \mathrm{sample} ; \mathrm{F}=9.89$ vs. $\mathrm{F}_{\text {crit, } 0.5 \%}=8.11$ ). Several species (e.g., Anopheles cruzii) seem to be more common below the waist, and have even been collected only below it (Wyeomyia incaudata and some other Wyeomyia).

Results of the species for which it was developed a statistical analysis and for the sum of mosquitoes indicate that it is recommendable to protect mostly below the waist for walking in the morning in this area. Young walkers, mostly students, besides people collecting wood and other materials, frequently use short trousers (bermudas) and low boots to walk in the forest. If people insist on leaving their legs exposed, they should apply repellents, preferably those containing deet ( $\mathrm{N}, \mathrm{N}-$ diethyl-metatoluamide) ${ }^{5}$. Thick socks combined with long trousers offer good protection when the bottoms of the trousers are tucked into the socks ${ }^{16}$; in fact, one of the trainees of our laboratory, who did not do this, was appalled by the entry of a large beetle into his paints. The fact that hard tick larvae micuins), snakes, ants and other harmful animals are common in this area, and probably in similar Atlantic forest areas reinforces the need to properly protect the legs, by applying deet both on the skin and on clothing.

Oc. scapularis is probably an important vector of Dirofilaria immitis in the State of Rio de Janeiro ${ }^{7}$, and this worm is very common (15\%) among dogs in the region of Conceição Lagoon ${ }^{1}$, some kilometers from the area where this study was developed. Two other species previously reported to be infected with microfilariae of D. immitis, Ae. albopictus ${ }^{2}$ and Wy. bourrouli ${ }^{7}$, were collected in UCAD, respectively on humans ${ }^{15}$ and in a bromeliad ${ }^{12}$. However, since this worm seems to occur mostly in association with dogs, houses and modified environments, the risk in uninhabited forests similar to UCAD is negligible. Oc. scapularis was also incriminated as a vector of Rocio virus in the State of São Paulo ${ }^{4}$; this dangerous virus should be investigated in UCAD and other localities in Santa Catarina, before human cases occur.

Astudy of preferences for body parts in diurnal mosquitoes in the canopy of Amazonian rain forest ${ }^{3}$ indicated that Haemagogus janthinomys preferred to land on the legs and mostly on the feet, while species of Sabethes preferred the head; the bait collector wore only bathing trunks. The study at UCAD included nine collections, totaling 8.6 hours, compared to 255 hours of collections ( 85 days, three hours per day) in the other study; moreover, the present study was developed on the ground, while in the Amazonian study mosquitoes were collected at 15 or $20 \mathrm{~m}$ above ground level. The mean number of mosquitoes collected per hour ( sum of collected mosquitoes/hour) were, respectively for the study in Amazon and that in UCAD, 2.9 and 41.6. Thus, the intensity of attack by mosquitoes seems to be much higher in the UCAD study when compared with the Amazonian study.

Sabethes mosquitoes were rare in the present study ( 0.35 / hour), in comparison with the Amazonian study (2.22/ hour). This rarity of mosquitoes of Sabethes in the UCAD study could be due to biological characteristics of the local species and to differences in methods, but it is more probably due to the scarcity of breeding sites. Sa. aurescens is currentlyverycommon in bamboo holes in $2003^{13}$, at one of the points of collection ( n. 9) of ${ }^{15}$, while 
bamboo internodes perforated by animals and tree-holes are very rare in the area (CB Marcondes- unpublished results). Two small holes (10-15ml of water) in a palm tree cited before ${ }^{12}$, near point 8 of ${ }^{15}$ have always had immature forms of mosquitoes, including Sa. albiprivus, Sa. purpureus and Toxorhynchites sp. (CB Marcondes: unpublished results). This indicates that the available breeding places in phytotelmata are well exploited by local mosquitoes. The three Sabethes mosquitoes were collected around 10:30 a.m., on November $1^{\text {st }}$, landing above the waist.

Studies on landing behaviour in which mosquitoes are collected for a long period (e. g. ${ }^{3}$ ) may show a depletion of the quantities collected after a peak of activity in the first few minutes. The rapid movement of the collectors/baits in the study of UCAD, between the points, may have stimulated some diurnal mosquitoes, resting in the vegetation, to bite, as previously observed ( see $^{17}$, p. 352). This behaviour is similar to that of walkers in the forest, and differences in the methods can impede a precise comparison between these studies.

The application of repellent on feet and ankles prevented bites of An. arabiensis on these parts of the body, and reduced by more than three-fold the total number of bites, modifying the proportion of bites on other parts from 18.9 to $100 \% 6$. Consequently, even with good protection of those parts of the body preferred by the mosquitoes, it is necessary to evaluate the transference of the mosquitoes to other parts; whenever this occurs, a more comprehensive protection is necessary.

More detailed studies on the landing behaviour of mosquitoes and other biting insects must be undertaken in the Atlantic forest, over a longer period and noting the environmental conditions during collection.

\section{ACKNOWLEDGEMENTS}

To Drs. Oswaldo Paulo Forattini and Iná Kakitani, and to Mr. Aristides Fernandes, of Faculdade de Saúde Pública of Universidade de São Paulo, for the useful comments, for the checking the identification of some mosquitoes and for training one of the authors (UP). To Dr. Maike Hering Queiroz, of Departamento de Botânica of Universidade Federal de Santa Catarina, for authorization to study the collections in UCAD, and to Mr. Silvânio G. Costa, for the help in the field work.

\section{REFERENCES}

1. Araujo RT, Marcondes CB, Sartor DC, Bastos LC. Canine dirofilariasis in the region of Conceição Lagoon, Florianópolis, and in the Military Police
Kennel, São José, State of Santa Catarina, Brazil. Veterinary Parasitology 113: 239-242, 2003.

2. Cancrini G, Frangipane di Regalbono A, Ricci I, Tessarin C, Gabrielli S, Pietrobelli M. Aedes albopictus is a natural vector of Dirofilaria immitis in Italy. Veterinary Parasitology 118, 195-202, 2003.

3. Dégallier N, Sá Filho GCN, Silva OV, Travassos-da-Rosa APA, Silva OV. Comportamento de pouso em partes do corpo humano de mosquitos da Floresta Amazônica (Brasil) (Diptera: Culicidae). Boletim do Museu Paraense Emilio Goeldi 6: 97-108, 1990.

3. Forattini OP. Culicidologia médica. Editora da Universidade de São Paulo, Vol. 2. São Paulo, 2002.

4. Forattini OP, Kakitani I, Massad E, Marucci D. Studies on mosquitoes (Diptera: Culicidae) and anthropic environment. 9- Synanthropy and epidemiological vector role of Aedes scapularis in South-Eastern Brazil. Revista de Saúde Pública 29: 199-207, 1995.

5. Fradin MS. Mosquitoes and mosquito repellents: a clinician's guide. Annals of Internal Medicine 128: 931-940, 1998.

6. Govere J, Braack LE, Durrheim DN, Hunt RH, Coetzee M. Repellent effects on Anopheles arabiensis biting humans in Kruger Park, South Africa. Medical and Veterinary Entomology 15: 287-292, 2001.

7. Labarthe N, Serrão ML, Melo YF, Oliveira SJ, Lourenço-de-Oliveira R. Potential vectors of Dirofilaria immitis ( Leidy 1856) in Itacoatiara oceanic region of Niterói Municipality State of Rio de Janeiro Brazil. Memórias do Instituto Oswaldo Cruz 93: 425-432, 1998.

8. Lane J. Neotropical Culicidae. Dixinae, Chaoborinae, tribes Anophelini, Toxorhynchitini and Culicini (genus Culex only). Universidade de São Paulo, São Paulo, Vol. 1, p. 1-548, 1953.

9. Lane J. Neotropical Culicidae. Tribe Culicini, Deinocerites, Uranotaenia, Mansonia, Orthopodomyia, Aedomyia, Aedes, Psorophora, Haemagogus, tribe Sabethini, Trichoprosopon, Wyeomyia, Phoniomyia, Limatus and Sabethes. Universidade de São Paulo, São Paulo, Vol. 2, p. 549-1112, 1953.

10. Lane JL, Cerqueira NL. Os sabetíneos da América (Diptera, Culicidae). Arquivos de Zoologia do Estado de São Paulo 3: 473-849, 1942.

11. Lopes OS, Sacchetta LA, Fonseca IE, Lacerda JP. Bertioga (Guama group) and Anhembi (Bunyamwera group), two new arboviruses isolated in São Paulo, Brazil. American Journal of Tropical Medicine and Hygiene 4: 131134, 1975.

12. Marcondes CB, Fernandes A, Paterno U, Müller GA, Pinho LC, Struffaldi DV. New records of mosquitoes from the southern Brazilian states of Santa Catarina and Rio Grande do Sul, with 18 species new for the States ( Diptera: Culicidae). Zootaxa 347: 1-6, 2003.

13. Marcondes CB, Mafra H. Nova técnica para o estudo da fauna de mosquitos (Diptera: Culicidae) em internódios de bambus, com resultados preliminares. Revista da Sociedade Brasileira de Medicina Tropical 36: 763-764, 2003.

14. Mitchell CJ, Forattini OP, Miller BR. Vector competence experiments with Rocio virus and three mosquito species from the epidemic zone in Brazil. Revista de Saúde Pública 20: 171-177, 1986.

15. Paterno U, Marcondes CB. Mosquitos antropofílicos de atividade matutina em trilha em Mata Atlântica em Florianópolis, Santa Catarina, Brasil (Diptera, Culicidae). Revista de Saúde Pública 38: 133-135, 2004.

16. Rozendaal JA. Vector control methods for use by individuals and communities. Geneva, World Health Organization, xii+412 p, 1997.

17. Service MW. Mosquito ecology: field-sampling methods. Chapman \& Hall, London, XIII, 1993. 